Piotr LizAK

Uniwersytet Pedagogiczny, Kraków

\title{
Przemiany w przemyśle samochodów osobowych w Polsce w latach zmian systemu gospodarowania
}

Postępujące procesy rozwoju gospodarczego i kulturowego, a także impulsy płynące z otoczenia międzynarodowego wpływają na zmiany kształtowania się różnej skali przestrzennych struktur przemysłowych w przestrzeni gospodarczej. Dotyczy to pojedynczych przedsiębiorstw, okręgów przemysłowych oraz przemysłu krajowego (Zioło 2000, 2008). Przedmiotem niniejszej pracy jest analiza procesu kształtowania się przemysłu samochodów osobowych w Polsce. Zmierzać będziemy do określenia etapów rozwoju i zmian jego potencjału ekonomicznego i produkcyjnego oraz wskazania zmian następujących we współczesnej strukturze polskiego przemysłu motoryzacyjnego.

Rozwój przemysłu samochodów osobowych w Polsce przebiegał w bardzo zróżnicowanych, zupełnie odmiennych warunkach polityczno-gospodarczych, które obejmowały trzy okresy: okres przedwojenny do 1939 r., okres gospodarki centralnie planowanej obejmujący lata 1945-1989 i okres transformacji gospodarki po 1989 r.

Początki przemysłu samochodowego na świecie dokonywały się na terenie Francji, Anglii, Niemiec, USA i Włoch. W tym czasie warunki polityczne i gospodarcze uniemożliwiały powstanie i rozwój tego przemysłu w Polsce. Na początku XX w. na terenach ówczesnej Polski nie podejmowano działań, które mogłyby doprowadzić do podjęcia produkcji pierwszego polskiego samochodu. Tereny dawnej Polski były wówczas częścią gospodarek Prus, Austrii i Rosji. W latach początkowego rozwoju motoryzacji na świecie dawne obszary Polski były obszarami nadgranicznymi państw zaborczych, co spowodowało, że stały się one nieatrakcyjne dla rozwoju przemysłu, w tym przemysłu samochodowego. Ze względów militarnych obszary te tworzyły tzw. rubieże, obejmujące tereny celowo nierozwijane, zwłaszcza w zakresie infrastruktury komunikacyjnej, która była ważnym czynnikiem lokalizacji przemysłu wielkofabrycznego. W konsekwencji na ziemiach tych nie było warunków dla rozwoju przemysłu samochodowego, stąd też na ziemiach polskich nie powstała żadna fabryka. Wpłynęło to na wieloletnie opóźnienie polskiego przemysłu samochodowego (Rychter 1987).

Na początku XX w. istniało natomiast na ziemiach dawnej Polski wiele małych warsztatów mechanicznych wykonujących naprawy samochodów marek zagranicznych, połączonych zazwyczaj z biurami przedstawicielstw fabryk samochodowych. Podczas I wojny światowej powstały niewielkie niemieckie i austriackie warsztaty wojskowe umieszczone przy zbrojowniach, m.in. w Krakowie, Rzeszowie i Brześciu. Jedyny większy zespół niemieckich warsztatów samochodowych (Centrale Werkstätte der Heeresverwaltung Ober-Ost) powstał w Warszawie przy ulicy Terespolskiej. 
Pierwszą polską fabrykę samochodów osobowych otwarto w 1920 r. w Warszawie przy ulicy Rakowickiej. Została ona uruchomiona z inicjatywy Stefana Kozłowskiego i Antoniego Frączkowskiego i produkowała samochody osobowe marki S.K.A.F. W 1925 r. hrabia Stefan Tyszkiewicz przeniósł z Francji do Warszawy nowoczesną fabrykę produkującą samochody marki Ralf-Stetysz (Rychter 1987). W tym samym roku w dawnych niemieckich warsztatach wojskowych władze polskie uruchomiły nowoczesną fabrykę samochodów osobowych pod nazwą Centralne Warsztaty Samochodowe (CWS), w której już w 1932 r. produkcję rozpoczął włoski koncern Fiat.

W okresie międzywojennym w Polsce istniało wiele montowni samochodów osobowych, m.in. montownia koncernu Ford (lata 1926-1928), GM (lata 1928-1931) i Citroën (lata 1930-1932), Lilpop Rau i Loewenstein (lata 1936-1939) w Warszawie oraz Praga w Oświęcimiu (Rummel 1985). Wybuch II wojny światowej nie tylko zahamował, ale doszczętnie zniszczył cały ówczesny dorobek motoryzacyjny kraju. Analizując polskie przedwojenne osiągnięcia w dziedzinie motoryzacji, należy przyjąć, że gdyby nie wybuch wojny, to Polska dysponowałaby w 1945 r. poza dużym i w pełni sprawnym przemysłem motoryzacyjnym, kilkusettysięcznym parkiem samochodowym, co w 1945 r. byłoby dużym osiąnnięciem. W układzie przestrzennym w tamtym okresie dominowała Warszawa, gdzie lokalizowane były nowe zakłady posiadające często najnowsze technologie. II wojna światowa spowodowała zniszczenie zakładów przemysłu motoryzacyjnego oraz dokumentacji technicznej.

Rozwój przemysłu motoryzacyjnego w Polsce w okresie powojennym, a szczególnie do roku 1970, przebiegał w bardzo ograniczonym zakresie. Sytuacja ta była konsekwencją dużych zniszczeń wojennych, braku infrastruktury, niskiej siły nabywczej ludności oraz określonej wizji rozwoju społecznego, zakładającej, iż w kraju nie należy rozbudzać w ludności konsumpcji ani indywidualizmu, które kojarzyły się ówczesnym elitom rządzącym z motoryzacją.

W 1948 r. koncern Fiat rozpoczął w Warszawie na Żeraniu budowę nowoczesnej fabryki samochodów osobowych. Na skutek zimnowojennych nastrojów przy zaawansowaniu robót budowlanych w ok. 20-25\% koncern Fiat zerwał umowę licencyjną. Zerwanie kontraktu nie oznaczało jednak rezygnacji z produkcji samochodów osobowych w Polsce. W $1951 \mathrm{r}$. ukończono budowę Fabryki Samochodów Osobowych (FSO) na Żeraniu i rozpoczęto produkcję samochodu marki Pobieda, przemianowanego później na Warszawa. W latach pięćdziesiątych w warszawskiej fabryce produkowano równolegle samochód osobowy marki Syrena. W latach sześćdziesiątych produkcja samochodów Warszawa i Syrena opierała się na przestarzałych technologiach. W celu unowocześnienia produkcji konieczne były zakupy nowych licencji i technologii. W 1965 r. podpisano umowę na zakup licencji od Fiata, dzięki której uruchomiono produkcje Fiata 1500 zmienionego później na model Fiat 125. Rosnąca produkcja w zakładzie FSO w Warszawie spowodowała potrzebę przeniesienia linii produkcyjnej samochodu Syrena do innego zakładu. Wybrano wówczas produkującą wcześniej silniki spalinowe i motopompy Wytwórnię Sprzętu Mechanicznego w Bielsku-Białej, gdzie od 1969 r. rozpoczęto produkcję samochodu Syrena. W ten sposób powstał w Polsce drugi zakład produkujący samochody osobowe.

W latach siedemdziesiątych, gdy w Polsce nastąpiło znaczne ożywienie gospodarcze, powstały plany uruchomienia nowej fabryki produkującej na masową skalę małolitrażowe samochody osobowe. Rozważano rozpoczęcie współpracy z koncernami motoryzacyjnymi z Europy Zachodniej czy USA, w tym m.in. z Volkswagenem, Citroënem, Renault, Fordem czy Fiatem. Władze zdecydowały się na kontynuację współpracy z koncernem Fiat, który za- 
oferował najlepsze warunki kontraktowe. W październiku 1971 r. doszło do podpisania umowy o współpracy technicznej i licencyjnej. Umowa ta przewidywała uruchomienie w Polsce produkcji samochodu małolitrażowego pod nazwą Fiat 126p oraz przebudowę i modernizację bielskich zakładów WSM, a także budowę nowego zakładu w Tychach. Inwestycja została zrealizowana w ciagu 7 lat. Cały kompleks zakładów przyjął nazwę Fabryka Samochodów Małolitrażowych (FSM).

Załamanie gospodarcze na przełomie lat siedemdziesiątych i osiemdziesiątych zahamowały rozwój polskiego przemysłu samochodów osobowych. Niewydolność centralnie planowanej gospodarki zaciążyła na losach rozwijającego się przemysłu samochodowego. Brak środków finansowych w wyniku przechwytywania przez budżet państwa zysków płynących $\mathrm{z}$ akumulacji przemysłu samochodowego doprowadził do jego stopniowego znacznego niedoinwestowania. Producenci nie mieli możliwości nie tylko unowocześnienia produkcji, ale nawet odtworzenia majątku, co w połączeniu z pętlą kredytową i rygorystyczną polityką fiskalną państwa doprowadziło branżę samochodową do upadku (Menes 1998).

W 1989 r. rozpoczęły się w Polsce przemiany gospodarcze związane z przejściem od gospodarki centralnie planowanej do gospodarki rynkowej. Przejście od nakazowo-rozdzielczego systemu gospodarczego do gospodarki rynkowej oznaczało początek olbrzymich przemian gospodarczych i politycznych zaznaczających się we wszystkich sektorach gospodarki, w tym także w przemyśle samochodowym.

Początek lat dziewięćdziesiątych był bardzo trudnym okresem dla polskiej motoryzacji. Polski przemysł motoryzacyjny znalazł się w poważnym kryzysie. Charakteryzował się przestarzała produkcją oraz brakiem nowoczesnych technologii, a także brakiem niezbędnych do funkcjonowania środków finansowych. Wszystkie przedsiębiorstwa branży motoryzacyjnej, w tym także producenci samochodów osobowych, znajdowały się w bardzo trudnej sytuacji, były często zagrożone bankructwem i całkowitą likwidacją.

W 1993 r. polski rząd zdecydował o wdrożeniu i realizacji długofalowej polityki przemysłowej, której głównym założeniem było uratowanie przed całkowitą likwidacją polskiego przemysłu motoryzacyjnego. Za najlepszą drogę do tego celu uznano powiązanie przedsiębiorstw krajowych z firmami zagranicznymi dysponującymi nowoczesnymi technologiami i wyrobami oraz rozległymi rynkami zbytu. Przyjęto tezę, iż tylko koncerny zagraniczne mogą szybko zrestrukturyzować przestarzałe zakłady, inwestując w nie znaczne środki finansowe. Realizacja wspomnianego wyżej programu ratowania polskiego przemysłu motoryzacyjnego przebiegała w dwóch etapach.

Etap pierwszy, obejmujący lata 1993-1996, przewidywał okresową ochronę i tworzenie warunków do stabilnej restrukturyzacji sektora motoryzacyjnego w celu poprawy konkurencyjności polskich produktów, wzrostu efektywności i innowacji, a także dostosowania polskich wyrobów (w tym także samochodów) do standardów światowych.

Zastosowano trzy zasadnicze drogi przekształceń polskiego przemysłu motoryzacyjnego: tworzenie spółek joint-ventures z partnerami zagranicznymi, sprzedaż całych przedsiębiorstw lub wydzielonych ich części inwestorom zagranicznym, tworzenie grup przemysłowych. Współpraca z inwestorami zagranicznymi na zasadach tworzenia spółek joint-ventures, które wprowadzały nowe technologie i nowoczesne produkty, dawała szansę na poprawę wyników finansowych i przekształcenia się w dobrze prosperujące przedsiębiorstwa. W ramach realizacji planu naprawy polskiego przemysłu samochodów osobowych w pierwszym okresie sprywatyzowano w drodze sprzedaży inwestorom zagranicznym: Fabrykę Samochodów Małolitrażowych (FSM) w Bielsku-Białej i Tychach, którą przejął 
koncern Fiat; Fabrykę Samochodów Osobowych (FSO) w Warszawie, którą przejął koncern Daewoo, oraz Fabrykę Samochodów Rolniczych (FSR) w Poznaniu, którą przejął koncern Volkswagen. Ponadto starano się tworzyć silne organizmy, tzw. grupy przemysłowe, które w wyniku wewnętrznego podziału pracy miały obniżyć koszty wytwarzania, a współpraca z inwestorami zagranicznymi miała ułatwić im dostęp do nowych technologii i produktów (Grupa Sobiesława Zasady).

Drugi etap długofalowej polityki przemysłowej rządu realizowany do dnia dzisiejszego polega na dalszym wspieraniu inwestycji w produkcję samochodów, a w szczególności na popieraniu inwestycji typu greenfield, tj. budowy nowych zakładów od podstaw. Koncerny zagraniczne rozpoczynały działalność poprzez tworzenie własnych filii lub jednostek mieszanych. Początkowo filie powstawały w wyniku przejmowania polskich przedsiębiorstw, ale stopniowo wzrastała w tym okresie liczba nowych realizowanych od podstaw projektów inwestycyjnych (Kamiński 2005).

Wśród zagranicznych koncernów, które zdecydowały się na inwestycje w Polsce w tym okresie, największe zaangażowanie wykazał koncern Fiat, który przejął w 1992 r. Fabrykę Samochodów Małolitrażowych obejmującą zakłady w Tychach i Bielsku-Białej, będące w trudnej sytuacji finansowej. Zakłady te były silnie powiązane technicznie z włoskim producentem i produkowały samochody na jego licencji. Koncern Fiat po przejęciu FSM wprowadził na jej miejsce trzy nowe firmy należące do Grupy Fiata. Powstały wówczas: Fiat Auto Poland, zajmująca się produkcją samochodów (Bielsko-Biała i Tychy) oraz wytwarzaniem linek i cięgien w zakładzie w Częstochowie, Teksid Poland, zajmująca się wykonywaniem wszelkich specjalistycznych odlewów dla przemysłu motoryzacyjnego, zlokalizowana w Skoczowie i Bielsku-Białej, oraz Magneti-Marelli, zajmując się produkcją zestawów wskaźników i elementów oświetlenia.

W 1993 r. na inwestycje w Polsce zdecydował się także niemiecki koncern Volkswagen. Koncern ten początkowo uruchomił montownię samochodów osobowych w Fabryce Samochodów Rolniczych w Poznaniu. W 1996 r. wykupił tereny i infrastrukturę po zlikwidowanej Fabryce Samochodów Rolniczych. Aktualnie w poznańskiej fabryce nie montuje się samochodów osobowych, lecz samochody dostawcze Volkswagen Transporter oraz produkuje samochody użytkowe Volkswagen Caddy.

W 1993 r. Fabryka Samochodów Ciężarowych (FSC) w Lublinie podjęła współpracę z firmą Peugeot, polegającą na montażu samochodów osobowych produkcji francuskiej. Po dwóch latach i po zmontowaniu 3500 sztuk samochodów Peugeot 405 współpracę z francuskim partnerem zakończono.

W pierwszej połowie lat dziewięćdziesiątych koncern GM uruchomił w Warszawie w fabryce na Żeraniu dużą montownię swych samochodów. Firma GM planowała znaczne inwestycje w warszawski zakład, nie wykluczając całkowitego jego przejęcia. Koncern GM zaoferował jednak znaczne mniej korzystne warunki i przegrał rywalizację o zakład FSO z koreańskim koncernem Daewoo.

Koncern Daewoo przejął od państwa Fabrykę Samochodów Osobowych w Warszawie i Fabrykę Samochodów Ciężarowych (FSC) w Lublinie. Koreański koncern znacznie zmodernizował warszawski zakład poprzez liczne inwestycje i wprowadzeniu do produkcji wielu nowych modeli samochodów. W Lublinie kontynuował produkcję samochodów dostawczych, uruchomił jednocześnie na okres około 3 lat montaż samochodów osobowych 
Daewoo Nexia. W 2000 r. koncern znalazł się w poważnych trudnościach finansowych i zaprzestał działalności inwestycyjnej, a następnie produkcyjnej w Polsce. Została ogłoszona upadłość fabryki w Lublinie. W kilka miesięcy później warszawska fabryka została przejęta przez koncern GM. W 2005 r. koncern GM wraz z ukraińskim Ukravto na bazie warszawskiego zakładu FSO utworzył spółkę joint-venture, w której 40\% akcji posiada koncern GM, a pozostałe $60 \%$ Ukravto.

W kilka lat po przegranej rywalizacji o warszawską fabrykę FSO koncern GM postanowił w 1998 r. uruchomić nowoczesną fabrykę produkującą samochody osobowe w Gliwicach. Pierwotne moce produkcyjne gliwickiej fabryki wynosiły 150 tys. sztuk rocznie. Od początku istnienia do 14 listopada 2007 r. gliwicka fabryka wyprodukowała łącznie 1 mln sztuk samochodów osobowych.

Sukcesy rynkowe Daewoo w Polsce spowodowały napływ inwestycji kolejnego koreańskiego koncernu motoryzacyjnego Kia. W latach 1996-1998 firma Kapena, specjalizująca się w produkcji autobusów, w swojej słupskiej fabryce uruchomiła niewielką montownię koreańskich samochodów osobowych marki Kia.

Najmłodszą fabryką produkującą samochody osobowe w Polsce jest niewielka ,rzemieślnicza" fabryka firmy Leopard Automobile AB zlokalizowana w Mielcu. Przedsiębiorstwo powstałe w 2002 r. produkuje luksusowe samochody sportowe, głównie na indywidualne zamówienie klienta.

W wyniku napływu zagranicznych inwestycji do Polski zakłady podniosły jakość produkowanych wyrobów i wprowadziły wiele nowych produktów. Nastąpiło również włączenie części gospodarki narodowej do globalnego systemu dużych korporacji i formowanie nowych wzajemnych powiązań. W wyniku zachodzących w tym okresie zmian doszło też do dywersyfikacji polskiego rynku motoryzacyjnego, polegającej na napływie inwestycji wspierających i otaczających pierwotne inwestycje.

Z przedstawionej analizy wynika, iż procesy transformacji gospodarki narodowej dokonały znacznych zmian w zakresie własności i przemian w polskim przemyśle samochodowym. Wiodące funkcje w tym zakresie przejęły ponadnarodowe korporacje przy znacznie zmniejszonym udziale dużych przedsiębiorstw państwowych.

Poszczególne okresy rozwoju przemysłu samochodów osobowych w Polsce odznaczają się wzrostem potencjału produkcji. W latach 1952-2008 produkcja wzrosła z 1,6 tys. sztuk (1952) do 840 tys. sztuk (2008), czyli 525-krotnie. Największe roczne przyrosty produkcji, tj. o 188 tys. sztuk, odnotowano w 2004 r., o 135 tys. sztuk w 2008 r. i o 115 tys. sztuk w 1993 r. Najbardziej drastyczny spadek poziomu produkcji nastąpił w latach: 2001 - spadek produkcji o 168 tys. sztuk, 2000 - spadek o 115 tys. sztuk i 1981 - spadek o 111 tys. sztuk (ryc. 1, tab. 1).

W analizowanym okresie nastapiła znaczna zmiana w strukturze przestrzennej polskiego przemysłu samochodów osobowych. Od narodzin przemysłu samochodowego w Polsce, jak już wspomniano, dominowała Warszawa, gdzie lokowano wszystkie inwestycje związane z przemysłem motoryzacyjnym. W latach siedemdziesiątych uruchomiono produkcję w Tychach i Bielsku-Białej, w latach dziewięćdziesiątych w Poznaniu i w Gliwicach. Obecna struktura przestrzenna zakładów produkujących samochody osobowe obejmuje miasta: Tychy, Gliwice, Warszawa, Poznań i Mielec (ryc. 2, tab. 2). 


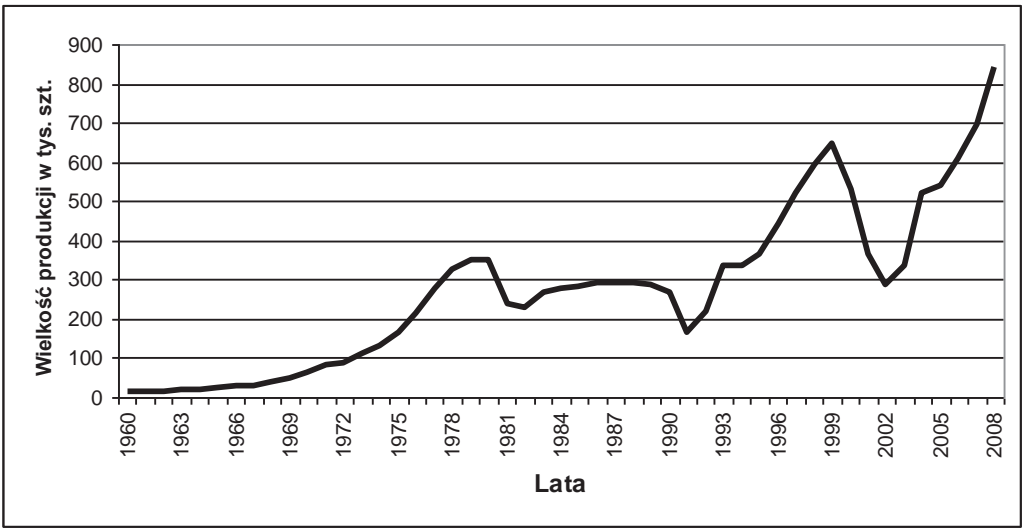

Ryc. 1. Produkcja samochodów osobowych w Polsce w latach 1960-2008

Źródło: opracowanie własne na podstawie GUS i OICA

Tab. 1. Produkcja samochodów osobowych w Polsce w latach 1950-2008

\begin{tabular}{|c|c|c|c|c|c|c|c|c|}
\hline Lata & $\begin{array}{c}\text { Wielkość } \\
\text { produkcji } \\
\text { w tys. }\end{array}$ & $\begin{array}{c}\text { Wskaźnik } \\
\text { dynamiki } \\
\text { produkcji }\end{array}$ & Lata & $\begin{array}{c}\text { Wielkość } \\
\text { produkcji } \\
\text { w tys. }\end{array}$ & $\begin{array}{c}\text { Wskaźnik } \\
\text { dynamiki } \\
\text { produkcji }\end{array}$ & $\begin{array}{c}\text { Watalkość } \\
\text { produkcji } \\
\text { w tys. }\end{array}$ & $\begin{array}{c}\text { Wskaźnik } \\
\text { dynamiki } \\
\text { produkcji }\end{array}$ \\
\hline $\mathbf{1 9 5 0}$ & 0,08 & & $\mathbf{1 9 7 0}$ & 64,00 & 128,00 & $\mathbf{1 9 9 0}$ & 266,00 & 93,33 \\
\hline $\mathbf{1 9 5 1}$ & 1,60 & 2000,00 & $\mathbf{1 9 7 1}$ & 85,00 & 132,81 & $\mathbf{1 9 9 1}$ & 167,00 & 62,78 \\
\hline $\mathbf{1 9 5 2}$ & 1,60 & 100,00 & $\mathbf{1 9 7 2}$ & 90,00 & 105,88 & $\mathbf{1 9 9 2}$ & 219,00 & 131,14 \\
\hline $\mathbf{1 9 5 3}$ & 1,60 & 100,00 & $\mathbf{1 9 7 3}$ & 113,00 & 125,56 & $\mathbf{1 9 9 3}$ & 334,00 & 152,51 \\
\hline $\mathbf{1 9 5 4}$ & 1,70 & 106,25 & $\mathbf{1 9 7 4}$ & 133,00 & 117,70 & $\mathbf{1 9 9 4}$ & 338,00 & 101,20 \\
\hline $\mathbf{1 9 5 5}$ & 4,00 & 235,29 & $\mathbf{1 9 7 5}$ & 164,00 & 123,31 & $\mathbf{1 9 9 5}$ & 366,00 & 108,28 \\
\hline $\mathbf{1 9 5 6}$ & 5,80 & 145,00 & $\mathbf{1 9 7 6}$ & 216,00 & 131,71 & $\mathbf{1 9 9 6}$ & 441,00 & 120,49 \\
\hline $\mathbf{1 9 5 7}$ & 8,00 & 137,93 & $\mathbf{1 9 7 7}$ & 279,00 & 129,17 & $\mathbf{1 9 9 7}$ & 520,00 & 117,91 \\
\hline $\mathbf{1 9 5 8}$ & 11,00 & 137,50 & $\mathbf{1 9 7 8}$ & 326,00 & 116,85 & $\mathbf{1 9 9 8}$ & 592,00 & 113,85 \\
\hline $\mathbf{1 9 5 9}$ & 14,00 & 127,27 & $\mathbf{1 9 7 9}$ & 350,00 & 107,36 & $\mathbf{1 9 9 9}$ & 647,00 & 109,29 \\
\hline $\mathbf{1 9 6 0}$ & 12,20 & 87,14 & $\mathbf{1 9 8 0}$ & 351,00 & 100,29 & $\mathbf{2 0 0 0}$ & 532,00 & 82,23 \\
\hline $\mathbf{1 9 6 1}$ & 14,00 & 114,75 & $\mathbf{1 9 8 1}$ & 240,00 & 68,38 & $\mathbf{2 0 0 1}$ & 364,00 & 68,42 \\
\hline $\mathbf{1 9 6 2}$ & 16,00 & 114,29 & $\mathbf{1 9 8 2}$ & 228,00 & 95,00 & $\mathbf{2 0 0 2}$ & 288,00 & 79,12 \\
\hline $\mathbf{1 9 6 3}$ & 18,00 & 112,50 & $\mathbf{1 9 8 3}$ & 269,00 & 117,98 & $\mathbf{2 0 0 3}$ & 334,00 & 115,97 \\
\hline $\mathbf{1 9 6 4}$ & 20,60 & 114,44 & $\mathbf{1 9 8 4}$ & 278,00 & 103,35 & $\mathbf{2 0 0 4}$ & 522,00 & 156,29 \\
\hline $\mathbf{1 9 6 5}$ & 24,80 & 120,39 & $\mathbf{1 9 8 5}$ & 283,00 & 101,80 & $\mathbf{2 0 0 5}$ & 540,00 & 103,45 \\
\hline $\mathbf{1 9 6 6}$ & 28,00 & 112,90 & $\mathbf{1 9 8 6}$ & 290,00 & 102,47 & $\mathbf{2 0 0 6}$ & 609,00 & 112,78 \\
\hline $\mathbf{1 9 6 7}$ & 28,00 & 100,00 & $\mathbf{1 9 8 7}$ & 293,00 & 101,03 & $\mathbf{2 0 0 7}$ & 695,00 & 114,12 \\
\hline $\mathbf{1 9 6 8}$ & 40,00 & 142,86 & $\mathbf{1 9 8 8}$ & 293,00 & 100,00 & $\mathbf{2 0 0 8}$ & 840,00 & 120,86 \\
\hline $\mathbf{1 9 6 9}$ & 50,00 & 125,00 & $\mathbf{1 9 8 9}$ & 285,00 & 97,27 & & & \\
\hline & $\mathbf{Z n}$ & 0 & & & & & \\
\hline
\end{tabular}

Źródło: opracowanie własne na podstawie GUS i OICA 


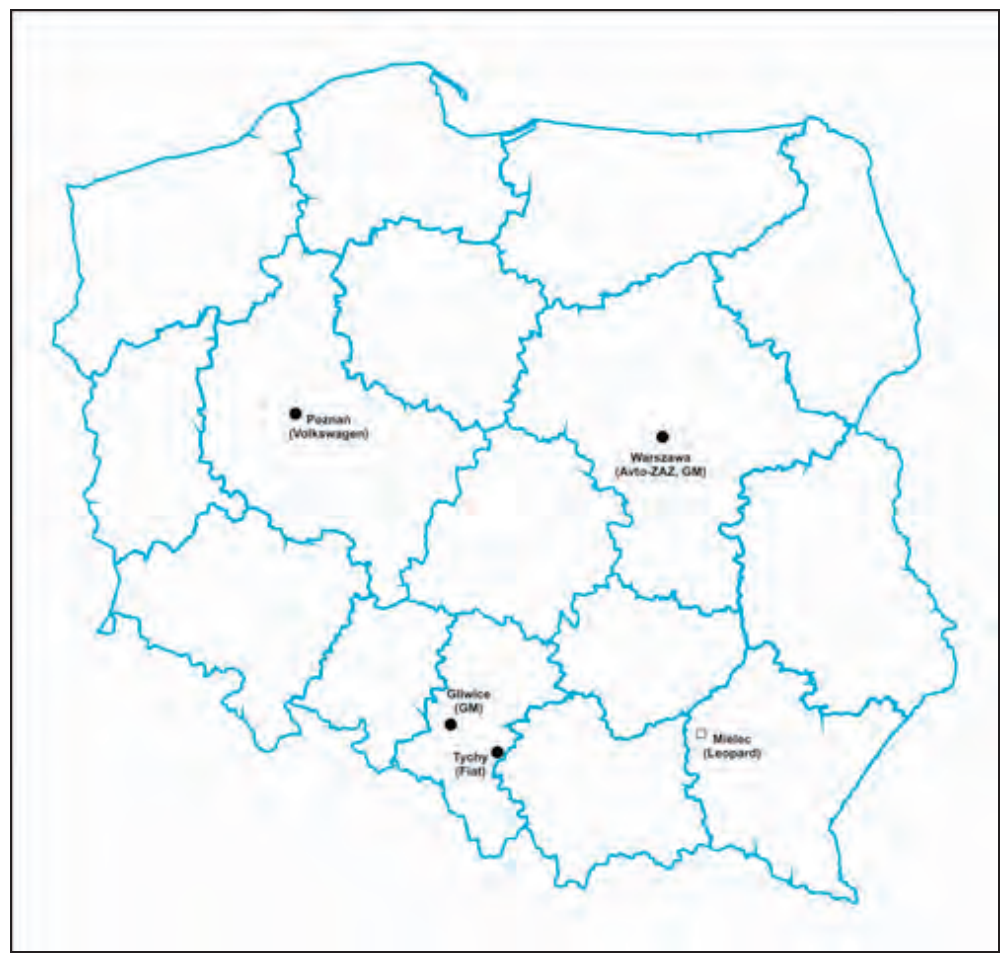

Ryc. 2. Zakłady produkujące samochody osobowe w Polsce w 2009 r.

Źródło: opracowanie własne

Tab. 2. Produkcja samochodów osobowych w Polsce w latach 2000-2008 wg zakładów

\begin{tabular}{|c|c|c|c|c|c|c|c|c|c|}
\hline \multirow[b]{2}{*}{ Lata } & \multirow[b]{2}{*}{$\begin{array}{l}\text { Produkcja } \\
\text { w Polsce }\end{array}$} & \multicolumn{8}{|c|}{ w tym } \\
\hline & & Fiat & $\begin{array}{l}\text { Wskaźnik } \\
\text { dynamiki } \\
\text { produkcji }\end{array}$ & GM & $\begin{array}{l}\text { Wskaźnik } \\
\text { dynamiki } \\
\text { produkcji }\end{array}$ & FSO & $\begin{array}{l}\text { Wskaźnik } \\
\text { dynamiki } \\
\text { produkcji }\end{array}$ & Volkswagen & $\begin{array}{l}\text { Wskaźnik } \\
\text { dynamiki } \\
\text { produkcji }\end{array}$ \\
\hline 2000 & 531,91 & 273,74 & ‘ & 97,39 & 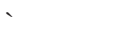 & 160,78 & - & 0,00 & - \\
\hline 2001 & 364,27 & 189,25 & 69,13 & 101,61 & 104,33 & 73,41 & 45,66 & 0,00 & ‘ \\
\hline 2002 & 288,36 & 164,85 & 87,11 & 97,67 & 96,12 & 25,84 & 35,20 & 0,00 & - \\
\hline 2003 & 333,73 & 193,75 & 117,53 & 76,51 & 78,34 & 63,47 & 245,63 & 0,00 & 다. \\
\hline 2004 & 522,72 & 292,97 & 151,21 & 116,59 & 152,39 & 50,91 & 80,21 & 62,25 & - \\
\hline 2005 & 539,91 & 273,03 & 93,19 & 128,61 & 110,31 & 51,01 & 100,20 & 87,26 & 140,18 \\
\hline 2006 & 608,00 & 281,64 & 103,15 & 186,41 & 144,94 & 50,58 & 99,16 & 89,37 & 102,42 \\
\hline 2007 & 695,89 & 346,62 & 123,07 & 187,30 & 100,48 & 86,76 & 171,53 & 75,21 & 84,16 \\
\hline 2008 & 840,36 & 452,96 & 130,68 & 171,55 & 91,59 & 132,40 & 152,60 & 83,45 & 110,96 \\
\hline
\end{tabular}

Źródło: opracowanie własne na podstawie danych OICA 
Współczesny przemysł samochodów osobowych w Polsce to nie tylko fabryki producentów samochodów osobowych, ale także nowe przedsiębiorstwa, które powstały w okolicach tych fabryk na skutek mechanizmu naśladownictwa i powstania nowych sieci kooperacyjnych. Wokół dużych zakładów produkujących samochody występują znaczne skupienia innych firm branży motoryzacyjnej współpracujących z fabrykami samochodów, jak producenci podzespołów, części zamiennych, chłodnic, amortyzatorów i in. Wśród tych firm można wymienić koncerny amerykańskie i francuskie, takie jak Delphi produkujące amortyzatory, komponenty tłoczne, części do silników w Tychach, TRW produkujące układy kierownicze, pasy bezpieczeństwa, poduszki powietrzne w zakładach w Częstochowie, CzechowicachDziedzicach i Gliwicach czy Valeo produkujące akumulatory, kompresory, chłodnice w zakładach w Czechowicach-Dziedzicach, Skawinie, Tychach i Chrzanowie (tab. 3).

Tab. 3. Kooperanci przemysłu motoryzacyjnego w Polsce w 2009 r.

\begin{tabular}{|c|c|c|c|c|}
\hline Koncern & $\begin{array}{c}\text { Pełna nazwa zakładów } \\
\text { wchodzących w skład kon- } \\
\text { cernu }\end{array}$ & $\begin{array}{l}\text { Kraj } \\
\text { pochodzenia } \\
\text { inwestora }\end{array}$ & Profil produkcji & Lokalizacja \\
\hline \multirow{7}{*}{ Delphi } & $\begin{array}{l}\text { Delphi Automotive Systems } \\
\text { Krosno }\end{array}$ & \multirow{7}{*}{ USA } & $\begin{array}{l}\text { Amortyzatory, } \\
\text { komponenty tłoczne, } \\
\text { części do silników }\end{array}$ & Krosno \\
\hline & $\begin{array}{l}\text { Delphi Automotive Systems } \\
\text { Skawina }\end{array}$ & & $\begin{array}{l}\text { Amortyzatory, } \\
\text { komponenty tłoczne, } \\
\text { części do silników }\end{array}$ & Skawina \\
\hline & $\begin{array}{l}\text { Delphi Automotive Systems } \\
\text { Błonia }\end{array}$ & & $\begin{array}{l}\text { Amortyzatory, } \\
\text { komponenty tłoczne, } \\
\text { części do silników }\end{array}$ & Błonie \\
\hline & $\begin{array}{l}\text { Delphi Automotive Systems } \\
\text { Ostrów Wielkopolski }\end{array}$ & & $\begin{array}{l}\text { Amortyzatory, } \\
\text { komponenty tłoczne, } \\
\text { części do silników }\end{array}$ & $\begin{array}{l}\text { Ostrów } \\
\text { Wielkopolski }\end{array}$ \\
\hline & $\begin{array}{l}\text { Delphi Automotive Systems } \\
\text { Jeleśnia }\end{array}$ & & $\begin{array}{l}\text { Amortyzatory, } \\
\text { komponenty tłoczne, } \\
\text { części do silników }\end{array}$ & Jeleśnia \\
\hline & $\begin{array}{l}\text { Delphi Automotive Systems } \\
\text { Gdańsk }\end{array}$ & & $\begin{array}{l}\text { Amortyzatory, } \\
\text { komponenty tłoczne, } \\
\text { części do silników }\end{array}$ & Gdańsk \\
\hline & $\begin{array}{l}\text { Delphi Automotive Systems } \\
\text { Tychy }\end{array}$ & & $\begin{array}{l}\text { Amortyzatory, } \\
\text { komponenty tłoczne, } \\
\text { części do silników }\end{array}$ & Tychy \\
\hline $\begin{array}{l}\text { Exide } \\
\text { Technologies }\end{array}$ & Exide Technologies Poznań & USA & Akumulatory & Poznań \\
\hline $\begin{array}{l}\text { The Goodyear } \\
\text { Tyre \& Rubber } \\
\text { Company }\end{array}$ & T.C Dębica S.A & USA & Opony & Dębica \\
\hline
\end{tabular}




\begin{tabular}{|c|c|c|c|c|}
\hline \multirow{4}{*}{$\begin{array}{l}\text { TRW Auto } \\
\text { Holdings INC. }\end{array}$} & $\begin{array}{l}\text { TRW Steering Systems } \\
\text { Poland } \\
\text { Pruszków, }\end{array}$ & \multirow{4}{*}{ USA } & Układy kierownicze & Pruszków \\
\hline & $\begin{array}{l}\text { TRW Polska } \\
\text { Częstochowa }\end{array}$ & & $\begin{array}{l}\text { Pasy bezpieczeństwa, } \\
\text { poduszki powietrzne }\end{array}$ & Częstochowa \\
\hline & $\begin{array}{l}\text { TRW Steering Systems } \\
\text { Czechowice-Dziedzice }\end{array}$ & & Układy kierownicze & $\begin{array}{l}\text { Czechowice- } \\
\text { Dziedzice }\end{array}$ \\
\hline & $\begin{array}{l}\text { TRW Braking Systems } \\
\text { Poland Gliwice }\end{array}$ & & Hamulce & Gliwice \\
\hline CF Gomma & $\begin{array}{l}\text { C.F. Gomma Poland } \\
\text { (Częstochowa) }\end{array}$ & Włochy & Elementy gumowe & Częstochowa \\
\hline \multirow{2}{*}{ Brembo S.p.A. } & $\begin{array}{l}\text { Brembo Polska } \\
\text { Dąbrowa Górnicza }\end{array}$ & \multirow{2}{*}{ Włochy } & Systemy hamulcowe & $\begin{array}{l}\text { Dąbrowa } \\
\text { Górnicza }\end{array}$ \\
\hline & Brembo Polska Częstochowa & & Systemy hamulcowe & Częstochowa \\
\hline Gillardini & Gillardini Polska & Włochy & Fotele & $\begin{array}{l}\text { Dąbrowa } \\
\text { Górnicza }\end{array}$ \\
\hline \multirow{2}{*}{ Magneti-Marelli } & $\begin{array}{l}\text { Magneti-Marelli Suspension } \\
\text { System }\end{array}$ & \multirow{2}{*}{ Włochy } & Zawieszenia & Sosnowiec \\
\hline & $\begin{array}{l}\text { Magneti-Marelli Exhaust } \\
\text { System }\end{array}$ & & Układy wydechowe & Sosnowiec \\
\hline Teksid Group & Teksid Iron Poland & Włochy & Odlewy żeliwne & Skoczów \\
\hline \multirow{2}{*}{$\begin{array}{l}\text { LG Philips } \\
\text { Displays Holding } \\
\text { B.V. }\end{array}$} & Philips Gniezno & \multirow{2}{*}{ Holandia } & Elementy oświetlenia & Gniezno \\
\hline & Philips Bielsko-Biała & & Elementy oświetlenia & Bielsko-Biała \\
\hline \multirow{3}{*}{ British-Vita } & $\begin{array}{l}\text { Vita Polymers Poland } \\
\text { Brzeg Dolny }\end{array}$ & Wlk. Brytania & $\begin{array}{l}\text { Plastikowe elementy } \\
\text { wykończenia }\end{array}$ & Brzeg Dolny \\
\hline & $\begin{array}{l}\text { Vita Polymers Poland } \\
\text { Lublin }\end{array}$ & \multirow{2}{*}{ Wlk. Brytania } & $\begin{array}{l}\text { Plastikowe elementy } \\
\text { wykończenia }\end{array}$ & Lublin \\
\hline & $\begin{array}{l}\text { Vita Polymers Poland } \\
\text { Szymanów }\end{array}$ & & $\begin{array}{l}\text { Plastikowe elementy } \\
\text { wykończenia }\end{array}$ & $\begin{array}{l}\text { Szymanów } \\
\text { k.Wrocławia }\end{array}$ \\
\hline Pilkington & Pilkington Sandomierz & Wlk. Brytania & Szyby samochodowe & Sandomierz \\
\hline AE Group & AE Group & Niemcy & $\begin{array}{l}\text { Odlewy aluminium na } \\
\text { potrzeby motoryzacji }\end{array}$ & \\
\hline \multirow{2}{*}{ Keiper } & Keiper Polska Skarbimierz & Niemcy & $\begin{array}{l}\text { Fotele samochodowe, } \\
\text { akcesoria }\end{array}$ & Skarbimierz \\
\hline & Keiper Polska Świebodzin & Niemcy & $\begin{array}{l}\text { Fotele samochodowe, } \\
\text { akcesoria }\end{array}$ & Świebodzin \\
\hline Polytec Interior & Polytec Interior Polska & Austria & $\begin{array}{l}\text { Podsufitki, elementy } \\
\text { plastikowe }\end{array}$ & $\begin{array}{l}\text { Tomaszów } \\
\text { Mazowiecki }\end{array}$ \\
\hline Michelin & Michelin Polska S.A & Francja & Opony & Olsztyn \\
\hline
\end{tabular}




\begin{tabular}{|c|c|c|c|c|}
\hline \multirow{6}{*}{ Valeo } & $\begin{array}{l}\text { Valeo Electric and Electronic } \\
\text { Systems }\end{array}$ & \multirow{6}{*}{ Francja } & $\begin{array}{l}\text { Alternatory, kompre- } \\
\text { sory rozruszniki }\end{array}$ & $\begin{array}{l}\text { Czechowice- } \\
\text { Dziedzice }\end{array}$ \\
\hline & $\begin{array}{l}\text { Valeo Autosystemy Systemy } \\
\text { Chłodzenia Silnika }\end{array}$ & & Chłodnice & Skawina \\
\hline & $\begin{array}{l}\text { Valeo Autosystemy Odział } \\
\text { Produkcji Wycieraczek }\end{array}$ & & Wycieraczki & Skawina \\
\hline & Valeo Autosystemy Oddział & & & \\
\hline & Modułów Czołowych & & cinvonte & гуспу \\
\hline & $\begin{array}{l}\text { Valeo Autosystemy } \\
\text { Odział Produkcji } \\
\text { Systemów Świetlnych }\end{array}$ & & $\begin{array}{l}\text { Lampy samochodowe: } \\
\text { przednie, tylne, prze- } \\
\text { ciwmgielne }\end{array}$ & Chrzanów \\
\hline
\end{tabular}

Źródło: opracowanie własne

Obecnie przemysł samochodów osobowych w Polsce kształtuje się w czterech obszarach: Bielsko-Biała, Tychy, Gliwice - związane z zakładami Fiata i GM, Warszawa-Łódź związana z dawnym FSO, obecnie UkrAvto-GM, Poznań - związany z fabryką Volkswagena, Wrocław - związany z zakładem Toyoty w Wałbrzychu i Jelczu Laskowicach oraz zakładami Volkswagena w Polkowicach.

Reasumując należy podkreślić, iż obserwujemy przeniesienie centrów produkcyjnych samochodów osobowych z Warszawy na teren Śląska oraz ich rozproszenia w Polsce południowej. Mało atrakcyjne dla tego rodzaju działalności są tereny Polski północnej i wschodniej.

Obecny kryzys gospodarczy nie ominął również polskiego przemysłu samochodów osobowych. W branży motoryzacyjnej w Polsce nastąpiło znaczne ograniczenie produkcji o $20 \%$ oraz zatrudnienia o $10 \%$, tj. o 15,6 tys. osób. Wprowadzenie w 2009 r. przez 12 państw członkowskich UE systemu dopłat do zakupu nowego samochodu dla właścicieli za złomowanie ponaddziesięcioletnich pojazdów doprowadziło do znacznego ożywienia produkcji w zakładach produkujących samochody osobowe w Europie i w Polsce. Najwięcej na wprowadzeniu dopłat skorzystali producenci samochodów małolitrażowych (Garczarczyk 2009; Woźniak, Walewska 2009), a wśród polskich producentów samochodów tyska fabryka Fiata, gdzie produkcja nadal wzrasta.

W latach sytuacji kryzysowej poszczególne koncerny motoryzacyjne w Polsce charakteryzowały odmienne zachowania na rynku motoryzacyjnym. W pierwszym półroczu $2009 \mathrm{r}$. tyska fabryka Fiata zwiększyła produkcję o 20\% w porównaniu z pierwszym półroczem 2008 r. i wyprodukowała 298 tys. szt. samochodów. Ten stan uzyskano dzięki produkcji modelu Panda, który odnotował wzrost sprzedaży na chłonnym niemieckim rynku o ponad 400\% (Żuliński 2009). W przeciwieństwie do Fiata fabryka Opla w Gliwicach nie uzyskała zwiększenia zamówień w związku z dopłatami. Produkcja w gliwickich zakładach po II kwartale 2009 r. wynosiła 60,7 tys. szt., tj. uległa zmniejszeniu o 45\% w porównaniu z pierwszym półroczem poprzedniego roku. Produkowane w Gliwicach samochody to większe modele, niecieszące się takim powodzeniem jak małe auta. Sytuację może poprawić produkcja najnowszego modelu Opel Astra IV, rozpoczęta w gliwickich zakładach 3 października 2009 r. (tab. 4). 
Tab. 4. Zmiany wielkości produkcji samochodów osobowych w poszczególnych zakładach w Polsce w 2009 r.

\begin{tabular}{|l|l|c|c|c|}
\hline \multicolumn{1}{|c|}{ Nazwa zakładu } & Lokalizacja & $\begin{array}{c}\text { Produkcja } \\
\text { po 6 mies. 2008 r. } \\
\text { w tys. }\end{array}$ & $\begin{array}{c}\text { Produkcja } \\
\text { po 6 mies. 2009 r. } \\
\text { w tys. }\end{array}$ & $\begin{array}{c}\text { Dynamika } \\
\text { produkcji } \\
2008 / 2009 \\
\text { w \% }\end{array}$ \\
\hline Fiat Auto Poland & Tychy & 248,80 & 298,60 & 120,0 \\
\hline $\begin{array}{l}\text { General Motors } \\
\text { Manufacturing Poland }\end{array}$ & Gliwice & 110,30 & 60,70 & 55,0 \\
\hline Volkswagen Polska & Poznań & $79,50^{*}$ & $67,6^{*}$ & 85,0 \\
\hline $\begin{array}{l}\text { Fabryka Samochodów } \\
\text { Osobowych }\end{array}$ & Warszawa & 87,50 & 21,00 & 24,0 \\
\hline Leopard AB & Mielec & b.d. & b.d. & b.d. \\
\hline
\end{tabular}

* w tym samochody użytkowe

Źródło: opracowanie własne na podstawie: Żuliński 2009; Woźniak Raszkowska 2009; Woźniak, Walewska 2009; Woźniak 2009 a,b,c,

Najbardziej dotknięta przez kryzys okazała się warszawska fabryka na Żeraniu. Produkcja w pierwszym półroczu 2009 r. spadła tam w porównaniu z 2008 r. o ponad $76 \%$ i po drugim kwartale 2009 r. wynosiła 21 tys. szt. W zakładzie Volkswagena w Poznaniu również odnotowano spadek produkcji sięgający około $15 \% \mathrm{w}$ stosunku do pierwszego półrocza ubiegłego roku. Tendencje wzrostowe zaznaczyły się w zakładach kooperantów głównych producentów samochodów, np. wałbrzyski zakład Toyoty produkujący skrzynie biegów i silniki do niewielkich samochodów nie odczuł kryzysu, gdyż dostarczał swoją produkcję do fabryki w Kolinie (Czechy) produkującej małe auta Citroën C1, Toyota Aygo czy Peugeot 107.

Kryzys gospodarczy wywiera istotny wpływ na decyzje zagranicznych inwestorów związanych z motoryzacją, zmusza do ciąłłego zmniejszania kosztów działalności. Polska przestaje już być krajem bardzo atrakcyjnym dla inwestycji, wpływa na to wzrost kosztów pracy, który przejawił się wzrostem płac o ok. 10-12\%. Również wzrost stabilności złotego do dolara ma wpływ na zmniejszenie opłacalności eksportu produktów z Polski do państw Europy Zachodniej. W związku z tym obserwujemy migracje zakładów przemysłowych, np. o przeniesieniu do Rumunii swojego zakładu produkującego części dla przemysłu motoryzacyjnego poinformowała w lipcu 2009 r. firma Takata-Petri z Wałbrzycha. Swoją fabrykę ma również zamknąc SEWS Polska należąca do japońskiego koncernu Sumitomo (IAR, 2009; Woźniak, Raszkowska 2009).

Rozwój motoryzacji w Polsce w latach 1918-2009 dokonywał się w różnych uwarunkowaniach społeczno-gospodarczych, lecz pomimo licznych trudności ogólna produkcja samochodów wykazywała tendencję wzrostową. W okresie transformacji gospodarki narodowej dokonały się znaczne zmiany w zakresie własności w polskim przemyśle samochodowym. Zmniejszał się udział państwa, a wiodące funkcje przejęły ponadnarodowe korporacje. Przemiany polityczno-gospodarcze i napływ bezpośrednich inwestycji zagranicznych do Polski umożliwiły podniesienie jakości produkowanych wyrobów oraz rozwinięcie produkcji nowych marek samochodów. Obecnie Polska zalicza się do grona 20 największych 
producentów samochodów osobowych, dostarczając na rynek 840 tys. szt. samochodów osobowych, tj. 1,6\% ogółu światowej produkcji.

W okresie obecnego kryzysu działalność producentów samochodów osobowych w Polsce warunkowały w dużej mierze programy wsparcia motoryzacji w postaci dopłat do zakupu za złomowanie starych aut wprowadzone w innych krajach Unii Europejskiej, głównie Niemiec, a także dopłaty krajów Europy Zachodniej do działalności produkcyjnej koncernów motoryzacyjnych. Przemysł motoryzacyjny w Polsce, mimo dużego wpływu na rozwój gospodarki kraju, nie jest w obliczu kryzysu traktowany jako priorytetowa branża. Nie podjęto bowiem, tak jak w innych krajach działań chroniących producentów samochodów osobowych. Słabnąca kondycja motoryzacji w Polsce potrzebuje wsparcia ze strony rządu oraz działań pozwalających utrzymać dotychczasowy poziom produkcji we wszystkich fabrykach w kraju.

(Referat wygłoszony w 2009 roku)

\section{Literatura}

Depesza Informacyjnej Agencji Radiowej (IAR) z dn. 16.07.2009.

Garczarczyk T., 2009, „Jakub Faryś, PZPM: Pomóżmy w końcu motoryzacji, http://motoryzacja.wnp. pl/jakub-farys-pzpm-pomozmy-w-koncu-motoryzacji,95330_1_0_0.html z dn. 30.11.2009.

Kamiński A., 2005, Europa Środkowo-Wschodnia w dziatalności koncernów międzynarodowych: na przykładzie koncernów motoryzacyjnych, Mater, Szczecin.

Menes E., 1998, Dylematy rozwoju motoryzacji indywidualnej w Polsce, Instytut Transportu Samochodowego, z. 87, Warszawa.

Pytlos C., 2009, Chevrolety ratunkiem dla FSO, „Dziennik Polska - Europa - Świat”, 25.08.

Raporty OICA za lata 1997-2008.

Rychter W., 1987, Dzieje samochodu, Warszawa.

Rummel A., 1985, Polskie konstrukcje i licencje motoryzacyjne w latach 1922-1980, WKit, Warszawa.

Woźniak A., 2009a, Motoryzacja ostro hamuje, „Rzeczpospolita”, 10.07.

Woźniak A. 2009b, Polska motoryzacja czeka na pomoc, „Rzeczpospolita”, 10.07.

Woźniak A. 2009c, Komu z górki, komu pod..., „Rzeczpospolita”, 25.09.

Woźniak A., Raszkowska G., 2009, Motoryzacja łapie oddech, Rzeczpospolita”, 12.08.

Woźniak A., Walewska D., 2009, Dopłaty ratuja motoryzację, „Rzeczpospolita”, 08.08.

Zioło Z., 2000, Problemy integracji międzynarodowej przemystu $w$ procesie zmian systemu gospodarowania, [w:] Problemy transformacji struktur przemystowych $w$ procesie przechodzenia do gospodarki rynkowej, red. Z. Zioło, Prace Komisji Geografii Przemysłu PTG, nr 1, Wydawnictwo Naukowe AP, Kraków, s. 13-21.

Zioło Z., 2008, Procesy transformacji przemysłowych układów przestrzennych na tle zmieniajacego sie otoczenia, [w:] Procesy transformacji ukladów przestrzennych przemystu na tle zmieniajacego się otoczenia, red. Z. Zioło, T. Rachwał, Prace Komisji Geografii Przemysłu PTG, nr 10, Wydawnictwo Naukowe AP, Warszawa-Kraków, s. 11-21.

Żuliński M., 2009, Fiat i kooperanci na fali, Wirtualny Nowy Przemysł, 22.11., http://motoryzacja. wnp.pl/fiat-i-kooperanci-na-fali,94691_1_0_0.html.

Witryny internetowe

http://www.moto.egospodarka.pl/46400,Opel-Astra-IV-ruszyla-produkcja-w-GM-Gliwice, 1,86,1. $\mathrm{html}$;

www.fso-sa.com.pl; 


\section{Transformations in car industry in Poland in the years of changes of the economic conditions}

The subject of this work is to present the process of forming car industry in Poland and the influence of the current economic crisis on its shape and condition. The aim of the work is to indicate changes that are observed in the current structure of the Polish automotive industry.

The article presents changes of the spatial structure of automotive industry in Poland in years 1918-2009. In the second part, an issue of the influence of the current economic crisis on general condition of the automotive industry in Poland is described. Moreover, the causes of changes of the spatial structure of the Polish automotive industry (resulting from the global economic crisis) are indicated and analyzed.

Mgr Piotr Lizak

Uniwersytet Pedagogiczny, Kraków

Instytut Geografii

Zakład Przedsiębiorczości i Gospodarki Przestrzennej

e-mail: lizak.piotr@wp.pl 